\title{
Integrating Liberal Economic Regulation with Environmental Protection: Ethiopia, Zambia, Mali and Ghana
}

\author{
Dennis 0. Agelebe \\ Center for Environmental Law, University of Cologne \\ dageleb1@uni-koeln.de
}

\begin{abstract}
Foreign investors and host African countries have a tied interest in the economy. The interaction of foreign direct investment (FDI) and the environment impacts on the natural world and the population in no small measure. As the interaction evolves, other factors, such as human rights, sustainable development and resource management also begin to shape economic activities. Their impact depends on the regulations and policies of recipient countries. Some researchers believe that the inflow of FDI makes government tighten its environmental regulation and policies, but such a finding is too generalised. The increase in global environmental consciousness shows that relaxed environmental policies have been part of the incentives for attracting FDI into Africa in past years. This paper focuses on how the regulations and policies of selected African countries influence their position in international investment agreements and how such agreements affect environmental laws. A sub-regional policy template is needed that will guide members of regional economic blocs like ECOWAS in framing balanced policies for the environment and FDI.
\end{abstract}

\section{Introduction}

Africa is the world's fastest-growing region for foreign direct investment (FDI) according to a study collated between 2014 and 2015 by the Financial Times (Financial Times 2017). The economic growth of African nations has been closely linked with inflow of FDI. Among the countries that have attracted appreciable volumes of FDI, those with strong oil and gas sectors or emerging information communication technology (ICT) sectors have, in the past four years, benefited most. Even countries like Egypt and Nigeria where security and political uncertainty have been major factors have witnessed surges in capital investment. Egypt in 2014, in the heat of political and security challenges, still edged other larger economies like Nigeria and 
South Africa in Africa to top the list of countries for capital investment, with an inflow of $\$ 18 \mathrm{bn}$ and a 42 percent increase in the number of projects funded by FDI in that year. Other countries including Morocco, Mozambique and Rwanda were havens for FDI due to their growth in real estate projects, renewable energy and ICT development. A major cause attributed to the surge in FDI inflow in Africa in the post-global recession is the investment climate which is influenced by different regulatory models in the various jurisdictions.

The investment climate of African countries, as a major factor that sets up the interest of serious foreign direct investors, refers below to the investment regulations of the FDI recipient. The global movement of investments from developed countries to developing countries has clearly shown that, beyond resource endowment, market size and growth potential, investors seek investor-friendly regulations and strong regulatory and nonregulatory institutions (Financial Times, 2017). Though most FDI in Africa tends to flow into resource-endowed countries, particularly the oil-producing countries, the regulatory ceiling for investment greatly influences the decisions of investors. This may involve issues such as environmental quality and sustainable development, and related systems of regulatory governance impacting environment and investment promotion. An analysis of how environmental protection has been integrated into regulations for FDI in four African countries - Ethiopia, Zambia, Mali and Ghana - shows that each represents a particular investment environment, characterised by challenges that can be attractive to investors wishing to take advantage of a prevailing socio-political situation. Since the major objective of this paper is to examine the tension between satisfying a conducive environment for FDI and an environmental protection regime, I examined countries that experienced irregular regime changes that may have caused changes in the system of investment and environmental governance - countries that are stable or unstable democratically but facing the challenge of weak regulatory regime or poor implementation of existing regulatory framework while also adopting a policy for attracting FDI.

\section{Objective}

Environment is a very strong factor that has been closely linked to economic growth through FDI (Dees 1998, p. 94). However, most recipient countries focus more on attracting much needed FDI by projecting economic gain and underplaying the possible environmental pain that FDI could unleash in the absence of appropriate regulations. Several factors are responsible for the regulatory approach of African countries to negotiating 
the terms of accepting FDI, including the system of governance, the size of the market and the resourcefulness of the country - natural, human and capital. One factor dominates: the resourcefulness of the recipient country (De Mello 1999). An objective of this paper is to examine the extent to which environmental protection is factored into regulations and policies that are made by African countries for attracting and regulating activities of FDI.

The extractive industries of Africa are very attractive for FDI, but attractiveness cannot be attributed to economic value alone but also to the assumed benevolence of the regulators of the industry (Moss, Ramachandran $\&$ Shah 2004). Regulation is a deliberate act of exercise of authority and it is susceptible to the wavering feature of national interest (Baldwin \& Cave 1999). The architecture of the regulatory set up in most African nations is wrapped around the concept of national survival rather than national pride. Scholarly literatures have linked the 'national survival' approach to lopsided, weak and exploitative international investment agreements, which are either tolerated by an existing regulatory structure or result in the construction of a control mechanism that is easily pressed to give in to the blackmail of the much needed 'national survival' by FDI operators (Haglund 2008). Across different African States, particularly the resource-rich ones, the aftermath of wrong regulatory postures in receiving and managing FDI can be seen in the phenomenon popularly known as 'resource curse' which has been inflicted on the population and environment by way of human rights abuse and environmental devastation.

The foundation of every economic system is the laws and regulations that provide the necessary institutional context for building an economy in line with conceived goals, within the realm of realities and reasonable forecasts. Because the environment cannot be exploited or managed in isolation, the scope of investment derivable from the environment and how it potentially negotiates the edges and curves of the economy of a State, is ideally resolved within growth plans. However, whether that can happen depends on the political economy of a State (Stavins 2004, p. 12).

A typical African legal regime regulates the resource sectors with state economic interests in view. The structure of such a regime pitches the economic drive against the environment. A socialist will be quick to point to capitalism as the root of such a self-destructive approach to investment regulation by an African country that is keen to plug into the global economic network through attractive incentives for FDI. However, it is important to note that historical factors also play a significant role in how the legal regime for an investment environment is structured in an African State. Legal regimes in Sub-Saharan Africa have over the years of their assimilation or 
adoption of their colonial precedents allowed their dynamism to tolerate external forces that tend to tilt the direction of their economic sectors. The unitary structure of governance in some countries has made fluidity of policy and flexibility in the regulatory process accommodate investment promotion with little or no considerations for the impact of such investments on the environment. Scholars have not well explained how economic interests of different entities are linked with a system of governance to influence a regulatory direction that favors an inflow of FDI whilst relegating to the background. factors that should be considered in the interest of the environment. Understanding the underlying nexus that features in policy and regulation making needs, it is argued here, a categorical examination of three systems of environmental governance: federalised, unified, and liberalised.

Environmental federalism is practiced when the regulatory powers of the central and component governments extend beyond their statutory domains. The central government concerns itself not only with attaining environmental standards within operations that falls under its direct jurisdiction, such as national carbon emission limits, clean energy production, environmental impact assessment, and natural resources utilisation and conservation. It also exercises its federal powers in enforcing laws that fall within the bounds of others areas mentioned in the constitution. While the central government has some exclusivity in the statutory powers granted it by the constitution for regulating of environmental affairs, the component governments have some powers granted it to regulate environmental issues of local concern. This is achieved by making by-laws, issuing permits for developmental projects and developmental planning, and by ensuring development follows plans laid down in the interest of the environment. Even where there are distinct environmental laws for national and local issues, neither government is ever satisfied with confining its policies within its respective jurisdictional ambit.

In a unified system, regulatory control of environmental affairs is centralised without any part of the component governments having any concurrent authority, statutory or conventional. Unlike the federalised system that is dynamic, this is traditionally static and not easily adaptive of global trends in environmental management and control. During the military regime in Nigeria, for example, the constitution was suspended and military decrees were enacted that vested in the federal military government the powers to regulate environmental affairs at the national and state level. In some other developing countries like Equatorial Guinea where there is a unitary structure of government, the exclusivity of powers to make provision for the environment rests in national laws and in one national body. Economic interest provides the best explanation for the adoption of the unified system. 
Central governments, in their desperation to protect national revenue stream derived from natural resources and exploited by foreign investors, make concessions that weaken environmental laws and reduce regulatory control and the monitoring of activities that have impacts on the environment.

Where the structure of regulation in the management and control of the environment is less restrictive amongst the component governments and the central government, it is a liberalised system. Within the governance structure of the central government, environmental laws are usually designed in such a way that the administration of the environment is not centralised in one authority and its application not across all sectors. For example, in Nigeria, the central government has the National Environmental Standard and Regulatory Authority (NESRA), while the state governments have their respective environmental regulatory agencies. The liberalised system may be confusing to investors when it appears there are multiple environmental regulatory frameworks or authorities to adhere to. That does not generally makes a country attractive to FDI, except where an FDI point of entrance into the country is through a special arrangement, perhaps by way of a bilateral international investment agreement. On the surface of a liberalised system, it could appear the various regulatory pathways leads to a common goal of ensuring a clean and sustainable environment, but policies are not always coordinated and may indeed conflict. In Nigeria, NESRA regulates environmental activities, but excluding the oil and gas industry. The Department of Petroleum Resources regulates all activities that could affect the environment in the downstream sector, while the Ministry of Petroleum Resources through the Nigerian National Petroleum Corporation regulates environmental activities in the upstream sector. In addition to the loose regulatory structure in Nigeria, the Nigerian Communications Commission sets its own standard in its Act, regulating environmental activities in the communication industry, in conflict with the standard set by NESRA.

The situation in Nigeria is not different in other African countries where the regulatory system for the environment is liberalised. In some cases, the component states have their own standards that conflict with the standard set by the central agency. Where regulation of the environment is not exclusive to the central government, the component states take advantage of the system, in most cases to weaken it to attract more investors to their state.

In all three systems summarised here, the interests of the economy usually overshadow the interest of the environment. 


\section{FDI, the Economy and the Environment}

It is a broadly accepted claim that FDI is an important source of capital which complements domestic investment, creates new jobs opportunities, and drives technological innovations that are tailored to the local economy (Akinlo 2004, p.627). According to Campos and Kinoshita (2002, p. 2), the positive impact of foreign direct investment on economic growth "seems to have acquired the status of stylised fact" in the international economics literature. However, some scholars have shown that the benefits accruable to recipient countries are conditioned upon certain factors present at the time of the entrance of FDI. For example, while FDI attracts technological innovations, it contributes to the growth of the economy only when the host country has a required minimum human capital base (Xu 2000, p.477). Some have also shown that for a country to gain significantly from FDI in terms of growth rate, there must be a well-developed financial market (Alfaro et al. 2004).

Other researchers have dissenting opinions on the impact of FDI on economic growth. FDI may impact negatively on the growth prospects of the recipient economy if it gives rise to a substantial reverse flow in the form of remittances of profits, particularly if resources are remitted through transfer pricing and dividends, or if transnational corporations obtain substantial or other concessions from the host country (Ojewumi \& Akinlo 2017). Whether the positives outweigh the negatives remains to be determined. Blomstrom, Lipsey \& Zejan (1994) concluded that FDI exerts a positive effect on economic growth, but there appears to be a threshold level of income above which FDI has positive effect on economic growth and below which it does not.

While the linkage of FDI and environment in sub-Saharan Africa attracts more attention when it produces negative impact, it is noteworthy that where regulations and enforcement have been effective, the nexus has had positive impact on the environment of the host country. South Africa is an example of a country that has effectively utilised its regulatory and enforcement mechanism to ensure that FDI operations in its extractive industries do not impact negatively on the environment. The Constitution of South Africa provides for the right to an environment that is not harmful to health or wellbeing and that seeks protection of the environment for the benefit of present and future generations (South African Government Gazette, 20 October 1998). Mining is regulated by several laws, the most important of which are the Minerals Act (Act 50 of 1991), the Mine Health and Safety Act (Act 29 of 1996) and the Minerals Development Act, 2002. The Department of Minerals and Energy oversees the making and enforcement of regulations for 
the extractive industry. As observed by Boocock (2002), environmental performance derived from FDI in the extractive industry has improved significantly over the years.

The relationship between economic growth and the quality of the environment remains to be considered. According to the hypothesis summarized by Grossman and Krueger (1991), followed up by Selden and Song (1994), Suri and Chapman (1998) and Agras and Chapman (1999), environmental pollution levels increase as a country develops. That is, economic growth brings about a reduction in environmental quality. But when income rises beyond a critical point, pollution levels begin to fall. However, none of the above researchers studied African countries to understand how the hypothesis relates to the specific African countries. Kim and Baek (2011) suggest that economic growth lowers the growth of energy emissions in the developed world, but environmental quality deteriorates during times of economic growth in developing economies. Using Nigeria as case study, Ajide and Oyinlola (2010) find significant negative impacts of FDI on per capita carbon emission while other financial development indicators have a significant and positive impact on carbon emission. Further research likely will show that the standard of regulation and enforcement in developed economies is far higher than standards in developing economies.

The present transitional phase of some economies of Africa comes at a steep price as different countries curry favour to quality for FDI from developed economies. The price they pay includes weakened environmental policies and regulations.

Individually, African countries approach towards protection of environment varies, depending on their socio-political orientation and economic condition. Some countries have taken significant steps by putting in place legislation that should address existing environmental issues and mitigate future concerns, but others are lagging. For countries that have demonstrated a good level of commitment to the environment through legislative actions, the challenges have been serious shortfalls in funding, lack of political will and, even where the political will is there, a great dearth in human capacity needed to implement policies, enforce laws and promote programs for the protection of the environment.

\section{Ethiopia}

Ethiopia approved its first comprehensive environmental policy in 1997 and subsequently put in place strategies and laws designed to support sustainable development (Government of Ghana 1997). Successive administrations have implemented a wide range of legal, policy, and 
institutional frameworks on the environment, water, forests, climate change, and biodiversity. The overall goal of its environmental policy is "to promote sustainable social and economic development", and the words "sustainable development" appear in many different environmental laws, including the Environmental Impact Assessment Proclamation and the Environmental Protection Organs Establishment Proclamation, as well as the Constitution, which guarantees the right to sustainable development in Article 43(1). While Ethiopia takes environmental issues more seriously than most African countries, there continue to be challenges of inadequate implementation and enforcement.

There are several investment laws in operation in Ethiopia. The more active ones are the Investment Proclamation No. 769/2012 (as amended by Proc. No. 849/2014) with its regulation No. 270/2012, the Mining Operations Proclamation No. 678/2010, the Petroleum Operations Proclamation No. 838/2014, the Energy Proclamation No. 810/2013 and the Transaction of Precious Minerals Proclamation No. 651/2009. Most of the laws explicitly integrate environmental protection with investment promotion. The Investment Proclamation presents general and specific investment goals within the context of the Ethiopian socio-economic system. According to Article 5 of the Proclamation, the general goal is to "improve the living standard of the people of Ethiopia through the realisation of sustainable economic and social development," while the specific goals include accelerating economic development, exploiting and developing the natural resources of the country, developing the domestic market, increasing foreign exchange earnings, encouraging balanced development, enhancing the role of the private sector in economic development, and creating ample employment opportunities. Though the preamble does not directly mention environmental interest amongst the specific goals, Article 38 of the proclamation makes it clear that investors must consider the interest of the environment in the course of their business activities: "Any investor shall have the obligation to observe the laws of the country in carrying out his investment activities. In particular, he shall give due regard to environmental protection."

As different law takes care of specific environmental concerns, the proclamation did not provide direction for all environmental protection activity that existing laws may have provided for. It means investors will have to acquaint themselves with all extant environmental laws relating to their activities. It is noteworthy, though, that Article 30(4)(d) requires the investment agency to assist investors in getting approval for an environmental impact assessment (EIA). Even in the absence of an explicit 
provision compelling investors to conduct EIA, implicitly investors are required to undertake EIA in compliance with any law that subjects their business activity to such assessment.

The environmental permit process is the meeting point for policy and implementation. Weak policy, law or regulation does not appear to be the challenge in the case of Ethiopia, but passive implementation or enforcement is. Issuing permits, as a crucial control mechanism for regulating activities of FDI as it concerns the environment in Ethiopia, is bedeviled with delays in implementation, not for lack of resources but because of corruption amongst public officials who easily overlook obvious lapses under the influence of industry operators. According to a Country Environmental Analysis conducted by the World Bank team in 2017, most of the laws lack implementing regulations and standards due to outdated regulatory practices that are out of touch with present environmental challenges. So investors find themselves with open spaces in the system that they can use to avoid adhering to global standards in the absence of municipal implementation mechanisms that are up-to-date. The report identified the regulatory approach as "command and control", which is unitary in nature without allowing the participation of other stakeholders, least of all the public.

\section{Zambia}

Zambia with its attractive economic attributes have been a darling to foreign direct investors in the post-Chiluba era. Recent reports have shown that the net foreign direct investment inflow increased significantly to US $\$ 1,179.6$ million from US\$486.1 million in 2016 (Bank of Zambia 2018). This is attributed to an increase in FDI liabilities inflow to US $\$ 1,107.5$ million from US $\$ 662.8$ million in 2016 , a growth rate of 67.1 percent, largely from increased investment in the mining industry. Zambia's mining economy has long been attractive and active with decades of mining experience, but the impact of the mining sector on the environment has been a source of concern to civil society in Zambia. Although the mining industry occupies a relatively small part of the land surface, it does have significant and often irreversible impacts.

Zambia's body of environmental law is contained in more than 33 pieces of legislation; it is fragmented with responsibilities assigned to at least tenline ministries. The 1997 Environmental Impact Assessment regulations require assessments for all investments that have a major impact on the environment and require adequate environmental mitigation measures. The Ministry of Tourism, Environment, and Natural Resources and the Environmental Council of Zambia have a comprehensive environmental 
mandate. In practice, however, environmental management is largely dependent on the interest and competence of line ministries, which do not give it a priority. The environmental institutions are not strongly linked to development planning, finance, and sector institutions, and are politically weak and lack human capacity. They also face severe funding constraints; environmental issues are heavily dependent on international funding (Lindahl 2014). As a result, Zambia largely fails to manage sustainably its environment and natural resources.

\section{Mali}

Mali has relatively well-developed environmental legislation and was in the process of establishing a political and institutional framework for improving the environment and dealing with climate change. In 2010, it established the National Agency for Environmental and Sustainable Development, which had responsibility for implementation of environmental policy and integrating responses across the bureaucracy.

Mali has a strategy for a green economy and climate change. The country has witnessed increased FDI from Asian giants, China in particular. The Agricultural Orientation law and the National Economic and Social Development Program have defined Mali's political desire to become an agricultural force for the benefit of farmers and the population generally. Impact assessments are compulsory and must be carried out according to Decree No. 08-346/P-RM. They are performed by specialist research units and validated by a government cross-departmental commission, which is supposed to act and decide independently from sector interests., According to law, a developer must prove that a project will have a positive impact on the farming community. The law also states that the developer is bound to take into account existing rights if these rights are legally sound. This, however, only applies to customary rights on unregistered land and not to registered lands, such as the land within the Niger Basin Authority area where most FDI is concentrated.

A coup and government crisis in 2012 resulted in a 90 percent reduction in the budget of the environmental department of the Ministry of Environment and Sanitation. There is also a low regard for environmental legislation and weak human capacity in the government for improving the environment. Progress is dependent on international financing, better legal frameworks, and strengthened human capacity with the political will for enforcement of its environmental laws. 


\section{Ghana}

A report by the World Bank (2007) shows that Ghana's economy backed by strong natural resources base is expanding at a considerable rate - the annual average GDP growth is about 6 percent. FDI has increased largely due to a stable democratic environment and the Growth and Poverty Reduction Strategies (GPRS II), a policy driven by agriculture and private sector development and backed by laws and regulations that opens the economy to FDI (Government of Ghana 2005).

However, for Ghana, the price for an aggressive and FDI-open driven growth is a very steep one for the environment. The natural resources upon which much of the livelihood of the economy depends is fast depleting at a rate that makes the future of its economy bleak. Crop yields have stagnated, and productivity has declined because of rampant soil erosion. Fish, timber, and non-timber forest product stocks are decreasing rapidly. Coastal towns are facing severe water shortages during the dry season. Wildlife populations and biodiversity are in serious decline. Health-related pollution - indoor and outdoor air pollution, and water and sanitation issues - have emerged as serious health threats for most of the population. Recent World Bank report on the estimates of the cost of environmental degradation suggest that the equivalent of 10 percent of GDP is lost annually through unsustainable management of the country's forests, land resources, wildlife, and fisheries and through health costs related to water supply and sanitation, and indoor and outdoor air pollution.

The case is no different in most of the sub-Saharan African states. Weak bureaucracies lack the political backing to ensure that FDI follows extant environmental laws for sustainable development. In countries where their environmental laws are impressive enough, enforcement is usually a tall order. Even when a nation has signed on to international conventions on protection of the environment, the environmental laws and standards are much lower than accepted international norms.

\section{Conclusion}

Africa needs growth at a rate that support its fast-growing population. But uncoordinated growth can be devastating on the environment, population and future generations. The African Union (AU) has made declarations on environment and development that encompass economic, infrastructure and socio-political growth. The primary objective of these declarations is to promote the balance of development with environmental protection in the continent. The first was the Kampala Declaration on the Environment for Development of 2002 and between 2002 and 2008 there were six other 
declarations on African environment and development, but they have ended up as declarations with no record of progress in implementation.

For sustainable development to be achieved through FDI in African countries, the sub-regional blocs are in a better position than the AU to draw up a frame-work that can be implemented. The Economic Community of West African States (ECOWAS), for example, could agree on a standard for its member states that the ECOWAS Commission can follow up and advise members on policy variations that may be necessary due to situations peculiar to them. The major advantage of a uniform sub-regional template or standard is that it will prevent exploitative investors from shopping for easier alternatives amongst neighbouring states when the standard of some are stricter than others. Such an approach at the sub-regional level may also protect the well-being of the people of the sub-region from trans-boundary effect of environmental pollution caused by the operations of an investor in a neighbouring country. A federalised system, where governments at all levels within a country will have a say on how the environment will be managed, will make decision making open and inclusive of the people directly affected by operations or proposed activities of FDIs in any area.

\section{References}

Agras, J. and Chapman, D. (1999). A Dynamic Approach to the Environmental Kuznets Curve Hypothesis. Ecological Economics, 28(2), 267-277.

Alfaro, L., Chanda, A., Kalemli-Ozca, S., and Sayek,S. (2004). FDI and Economic Growth, the Role of Local Financial Markets. Journal of International Economics, 64, 113-134.

Ajide, K.B. and Oyinlola, M.A. (2010). Does the level of Economic Growth influence Environmental Quality in Nigeria: A Test of Environmental Kuznets Curve (EKC) Hypothesis? Pakistan Journal of Social Sciences, 7(4), 325-329.

Akinlo, A.E. (2004). Foreign Direct Investment and Growth in Nigeria: An Empirical Investigation. Journal of Policy Modelling, 26, 627-639.

Baldwin, Robert E. and Cave, Martin. (1999). Understanding Regulation: Theory, Strategy and Practice. Oxford, Oxford University Press.

Bank of Zambia. (2018). Foreign Private Investment \& Investor Perceptions in Zambia - 2018. Government of Zambia: Balance of Payments Statistical Committee. www.boz.zm/ForeignPrivateandInvestorPerce ptionReport2018.pdf

Blomstrom, M., Lipsey, R. E., \& Zejan, M. (1994). What explains the growth of developing countries? In Baumol, W., Nelson,R., and Wolff E. N. 
(eds.), Convergence of productivity: Cross-national studies and historical evidence. New York: Oxford University Press, 243-259.

Boocock, Colin Noy. (2002). Environmental Impacts of Foreign Direct Investment in the Mining Sector in Sub-Saharan Africa. Paper delivered to the OECD Conference on Foreign Direct Investment and the Environment Lessons to be Learned from the Mining Sector (7 - 8 February).

Campos, N. F. and Kinoshita, Y. (2002), Foreign Direct Investment as Technology Transferred: Some Panel Evidence from the Transition

Economies. University of Michigan: William Davidson Working Paper Number 438 (January).

Dees, S. (1998). Foreign Direct Investment in China: Determinants and Effects. Economics of Planning, 31: 175-94.

De Mello Luiz R. (1999). Foreign Direct Investment-led Growth: Evidence from Time Series and Panel Data. Oxford Economic Papers, 51: 133154.

Government of Ethiopia. (1997). Environmental Policy, www.epa.govet /Download/Proclamations/ENVIRONMENT\%20POLICY\%20OF\% 20ETHIOPIA.pdf..

Government of Ghana. 2005. National Development Planning Commission. Ghana Poverty Reduction Strategy [GPRS II]. Coordination Programme for the Economic and Social Development of Ghana (2006-2009).

Grossman, G.M. \& Krueger, A.B. (1991). Environmental Impacts of a North American Free Trade Agreement. NBER Working Paper No. 3914.

Haglund, D. (2008). Regulating FDI in weak African states: A case study of Chinese copper mining in Zambia. The Journal of Modern African Studies, 46(4), 547-575.

Kim, H. S., \& Baek J. (2011). The Environmental Consequences of Economic Growth Revisited. Economic Bulletin, Vol. 31, no. 2, pp. 1 -13 .

Lindahl, Joanna. (2014). environmental impacts of mining in Zambia: Towards better environmental management and sustainable exploitation of mineral resources. Geological Survey of Sweden Report. http://resource.sgu.se/produkter/sgurapp/s1422-rapport.pdf

Moss, Todd J., Ramachandran, V. \& Kedia Shah, M. (2004). "Is Africa's Skepticism of Foreign Capital Justified? Evidence from East African Firm Survey Data", Working Paper No. 41, Washington DC: Centre for Global Development. https://www.cgdev.org/publication/ 
africa $\% \mathrm{E} 2 \% 80 \% 99 \mathrm{~s}$-skepticism-foreign-capital-justified-evidenceeast-african-firm-survey-data.

Ojewumi, Sunday Johnson and Akinlo, Anthony Enisan. (2017). Foreign Direct Investment, Economic Growth and Environmental Quality in Sub-Saharan Africa: A Dynamic Model Analysis. African Journal of Economic Review, 5, I, 48-68.

Selden, T. M. and Song, D. Q. (1994). Environmental Quality and Development: Is there a Kuznets Curve for Air Pollution Emission. Journal of Environmental Economics and Management. 27: 147-162.

Stavins, Robert N. (2004). Introduction to the Political Economy of Environmental Regulations. Discussion Paper 04-12 https://ageconsearch.umn.edu/bitstream/10876/1/dp040012.pdf

Suri, V. and Chapman, D. (1998). Economic Growth, Trade and Energy: Implications for the Environmental Kuznets Curve. Ecological Economics, 25(2): 195-208.

World Bank. (2007). Country Assistance Strategy for Ghana. Report No. 39822-GH. (May 31).

Xu, B. (2000). Multinational Enterprises, Technology Diffusion, and Host Country Productivity Growth. Journal of Development Economics, 62, 477-493. 